Proc. Estonian Acad. Sci. Biol. Ecol., 2002, 51, 4, 257-276

\title{
Phytobenthic microcoenoses along Estonian exposed seashores
}

\author{
Triin Reitalu ${ }^{\mathrm{a}^{*}}$, Jaanus Paal ${ }^{\mathrm{a}}$, and Georg Martin ${ }^{\mathrm{b}}$ \\ a Institute of Botany and Ecology, University of Tartu, Lai 40, 51005 Tartu, Estonia; triinr@ @ot.ee, \\ jpaal@ut.ee \\ b Estonian Marine Institute, University of Tartu, Marja 4D, 10617 Tallinn, Estonia; \\ georg@klab.envir.ee
}

Received 16 October 2001, in revised form 19 June 2002

\begin{abstract}
Distribution and environmental range of phytobenthic microcoenoses along the exposed shores of the northeastern part of the Baltic Sea in Estonia are described. A total of 104 biomass samples were clustered into distinct micro-associations, and 35 composite samples into six community types. The Fucus vesiculosus community type is the most heterotoneous in the study area, including microcoenoses of various micro-associations. The other community types are more homotoneous. Phytobenthic microcoenoses at sites are related mainly to the depth of the seabed. Most of the microcoenoses have a more or less local distribution; only microcoenoses of the Fucus vesiculosus micro-association were found throughout the study area.
\end{abstract}

Key words: Baltic Sea, biomass, communities, distribution, micro-associations.

\section{INTRODUCTION}

The history of benthic macroalgal investigations along the Estonian shoreline dates back to the late 18th century. More than 150 published papers and manuscripts describe the species composition and the ecology of benthic macroalgae in the coastal areas of the southern part of the Gulf of Finland, northern part of the Gulf of Riga, and the West Estonian Archipelago area (Fischer, 1778; Gobi, 1874, 1877; Svedelius, 1902; Häyrén, 1929-30; etc.). Most of these publications have a strong floristic orientation. The first attempts to create a classification system for the benthic algal communities of Estonian coastal waters were made in the 1970s by Trei (1973) and Kukk $(1978,1979)$. These studies, quite similar in structure and principles of classification, are based on empirical interpretation of large amounts of qualitative and semi-quantitative data collected over several

\footnotetext{
*Corresponding author, triinr@hot.ee
} 
decades. Martin et al. (2000) developed a classification for benthic littoral communities of the West Estonian Archipelago area based on cluster analysis.

All the classification systems of phytobenthic vegetation elaborated in Estonia so far have been compiled on a community scale. Either the descriptive data generalized over the whole visually boardered community are used, or, in the case of quantitative studies, the data of small quadrats from one community are averaged and these composite samples (Gauch, 1982) are then subjected to clustering. The constitutional components (synusiae, microcoenoses) of phytobenthic communities have not been considered in Estonia or in the neighbouring Baltic countries. At the same time, these components represent a challenging problem in the detailed study of vegetation classification structure on different scales. The classification system obtained by composite samples lacks an overview of the infrastructure of communities. The high values of standard error, or coefficient of variation, calculated for cluster centroids cannot give more than a hint of the possible intricate community pattern. The use of two parallel classifications - one based on clustering of single small quadrats, and the other operating with composite samples - is a straightforward technique for identifying spatial homogeneity of communities (resp. vegetation belts), as well as internal homotoneity (sensu Nordhagen, 1943; Dahl, 1957) of community types.

In the last decades the methods of identifying the environmental factors and biotic interactions determining the structure and distribution of communities have developed rapidly. It has been found that in the Baltic Sea the formation of phytobenthic communities in the shallowest parts depends mostly on wave action, and in deeper areas, on the availability of light and suitable substrate, while biotic interactions have a minor role to play (Kautsky, 1988; Kautsky \& van der Maarel, 1990; Kiirikki, 1996). In Estonian waters, phytobenthos-environment interactions have recently most thoroughly been studied in the Gulf of Riga and the Väinameri (Martin, 1999; Kautsky et al., 1999; Martin et al., 2000). The most important environmental factor determining the structure of phytobenthos in these areas is the nature of the substrate (Kautsky et al., 1999; Martin et al., 2000). The quantitative and qualitative characteristics of phytobenthos have a strong regional pattern in the Gulf of Riga (Martin, 1999) as well as in the Väinameri (Martin et al., 2000).

Comparison of community classifications from different periods reveals temporal alterations in species composition and abundance in communities. There can be small-scale local fluctuations of these parameters and large-scale irreversible changes over larger areas. Alterations in phytobenthic communities, e.g. the large-scale decline of Fucus vesiculosus during the last decades, have been described in many parts of the Baltic Sea (Kangas et al., 1982; Mäkinen et al., 1984; Vogt \& Schramm, 1991; Rönnberg et al., 1995; Schramm \& Nienhuis, 1996). In Estonia, small-scale changes in phytobenthos composition have also been recorded (Kukk \& Martin, 1992; Kotta et al., 2000).

The aim of the present study is (i) to establish and compare the classification systems of the phytobenthic vegetation of Estonian exposed coasts on a microcoenosis scale as well as on a community scale; (ii) to evaluate the correspondence 
between the obtained results and community types of former investigations, and (iii) to estimate the environmental factors determining the distribution of microcoenoses of different microassociations.

\section{MATERIAL AND METHODS}

\section{Study area}

The study area covers the northeast Baltic Sea including the northern and western coasts of Estonia (Fig. 1). Altogether, ten sites along the coast were investigated: Kunda, Eru, Lohusalu, and Nõva in the Gulf of Finland; Kõiguste in the Gulf of Riga; and Kaugatuma, Küdema, Kõpu, Saxby, and Tjuka in the Baltic Proper. The shoreline of the area is quite complex with many islands, islets, and bays. Study sites were chosen to represent the coastline free from direct riverine inputs and with similar exposure and bottom characteristics. The dominating substrates were limestone rock, stone, and sand; in most cases they formed an intermixed pattern. In Kõiguste, Kaugatuma, Saxby, Tjuka, Kõpu, Nõva, Lohusalu, and Kunda the substrate was a mixture of sand, gravel, and stones; in Küdema and Nõva there was limestone covered with granite stones. The salinity range along the studied coastline was from $7 \%$ on the Estonian western coast to $5 \%$ in the middle of the Gulf of Finland (Kukk, 1979; Trei, 1991).

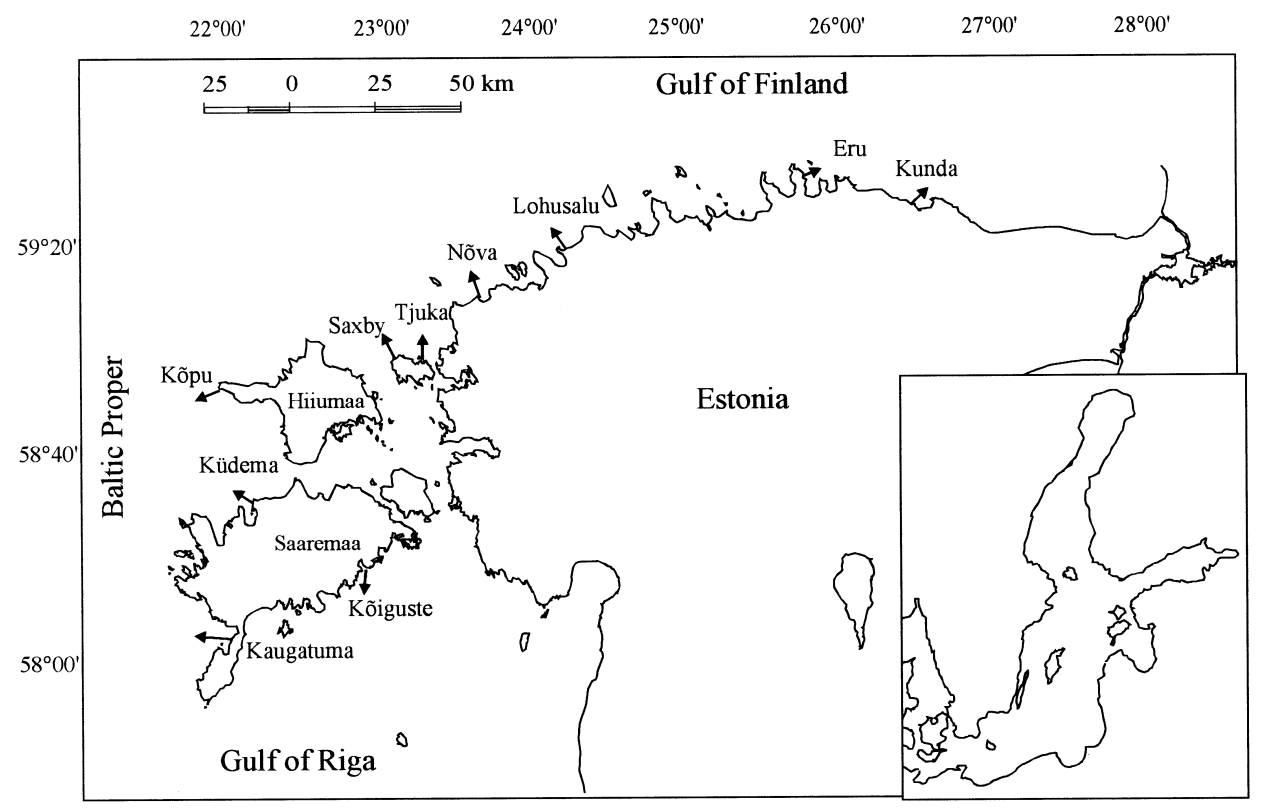

Fig. 1. Study area in the Baltic Sea and the location of sampling sites on the Estonian coast. Arrows mark the location and direction of transects. 


\section{Sampling}

The sampling was performed from the end of July to the beginning of October 1998. A transect from the water's edge to the lower vegetation limit was used at each site in order to describe the bottom vegetation and collect samples. The transects were described and the samples were taken using SCUBA-diving techniques. The transects were of different lengths $(0.2-6 \mathrm{~km})$ depending on the slope of the shore. If the transect was short, the diver swam the whole distance; in long transects the divers performed 50-100 m subtransects at given depth intervals. Along each transect, the divers recorded the type of substrate and the exact depth according to depth gauge. In every vegetation belt, estimated according to the dominating plant species, quantitative samples were collected by tossing three frames at random. Square frames of $0.2 \times 0.2 \mathrm{~m}$ were used. Whenever the composition of the dominating species changed or their total cover dropped to less than $25 \%$, the belt was sampled again. The total number of samples collected and analysed during the present investigation was 104 .

In the samples all specimens were identified, most of them to species level. Chara spp. and Enteromorpha spp. were identified to genus level, and the brown filamentous algae Pilayella littoralis and Ectocarpus confervoides were not separated. The nomenclature of algae is given according to Nielsen et al. (1995), and that of higher plants according to Leht (1999). The dry weight of the specimens of every taxon was measured; the samples were dried at $60^{\circ} \mathrm{C}$ for two weeks before weighing. The value of taxon biomass in the sample was calculated as dry weight per square metre.

\section{Data processing}

To evaluate the importance of exposure for bottom communities, the surface exposure index was calculated for each site according to Baardseth (1970). Substrate hardness was estimated by ordering the substrates from 1 (hard rock) to 11 (mud).

In order to select an optimal clustering method, various similarity measures (Manhattan distance, Euclidean distance, chord distance) and algorithms (single linkage, average linkage, minimal incremental sum of squares) were compared. The latter grouping algorithm and Euclidean distance gave the best interpretable results. Cluster analysis was performed in two stages. At first, data of single $0.2 \times 0.2 \mathrm{~m}$ sample quadrats were used; after that, the data of three quadrats representing the same vegetation belt (community) were averaged, and these composite samples were treated as separate data sets. To reduce the influence of dominant taxa and to approximate the distribution of the species' values to a normal distribution, the data were $\log 10$-transformed before clustering. Cluster analysis was carried out by means of the SYN-TAX 5.02 program package (Podani, 1993). The quality of the dendrogram was evaluated by the cofenetic correlation coefficient (Sokal \& Rolf, 1973; Podani, 1994). 
In order to measure the degree of mutual distinctness or continuity between clusters, the $\alpha$-criterion (Duda \& Hart, 1976) was used. To obtain a better interpretation of the estimates, the corresponding probabilities were applied as coefficients of indistinctness (CI) (Paal, 1987) instead of the direct values of the $\alpha$-criterion. At first, all the dendrogram branches including at least three objects were considered as clusters. If the $\mathrm{CI}$ for the neighbouring clusters in the dendrogram was higher than 5.0, the clusters could be merged from a statistical point of view and the continuum analysis was started iteratively again. When merging the clusters their interpretability was also taken into account.

The difference between environmental conditions in clusters was tested by one-way analysis of variance, carried out by the program package STATISTICA 5.1 (StatSoft, Inc., 1998).

Ordination was performed by the program package CANOCO for Windows Version 4.02 (Ter Braak \& Šmilauer, 1998); canonical correspondence analysis (CCA) with default settings was used. The significance of the first two ordination axes was tested by the Monte Carlo permutation test (199 unrestricted permutations). The importance of environmental variables was tested in forward-selection procedure using Monte Carlo permutation tests. The results of ordination analyses were visualized by means of the program package CanoDraw 3.0 (Šmilauer, 1992).

\section{RESULTS AND DISCUSSION}

\section{Cluster analysis}

The dendrogram of single quadrats has three large branches, all divided further into several smaller units (Fig. 2). On the basis of continuum analysis, a ten-cluster solution was accepted. The cofenetic correlation of the dendrogram is quite high (0.71), confirming a rather good correspondence between the dendrogram and the real data structure and the suitability of the chosen clustering algorithm. Taking into account that, in the current study, plants of all growth-forms occurring in the quadrats were considered, the term 'microcoenosis' is correct for these vegetation samples, while units of their classification can be called micro-associations (Barkman, 1964; Korchagin, 1976).

The first clearly separated branch of the dendrogram is divided into three clusters, all mutually indistinct $\left(\mathrm{CI}_{1,2}=43.4, \mathrm{CI}_{1,3}=33.4, \mathrm{CI}_{2,3}=73.1\right)$. On that basis these clusters should be merged, but as they all have certain biological peculiarities the clusters were accepted despite their indistinctness. The first cluster includes epiphyte-rich (mainly filamentous brown algae) Fucus vesiculosus microcoenoses (Table 1); in the second cluster $F$. vesiculosus is a single dominant, and in the third cluster there are several comparatively abundant species (Furcellaria lumbricalis, Polysiphonia fucoides, Elachista fucicola, Cladophora rupestris) in addition to $F$. vesiculosus and filamentous brown algae. According of this, the first three clusters can be interpreted as variants of the $F$. vesiculosus dominated micro-association with a very high biomass. Clusters with dominating $F$. vesiculosus are all clearly distinct from the others. 


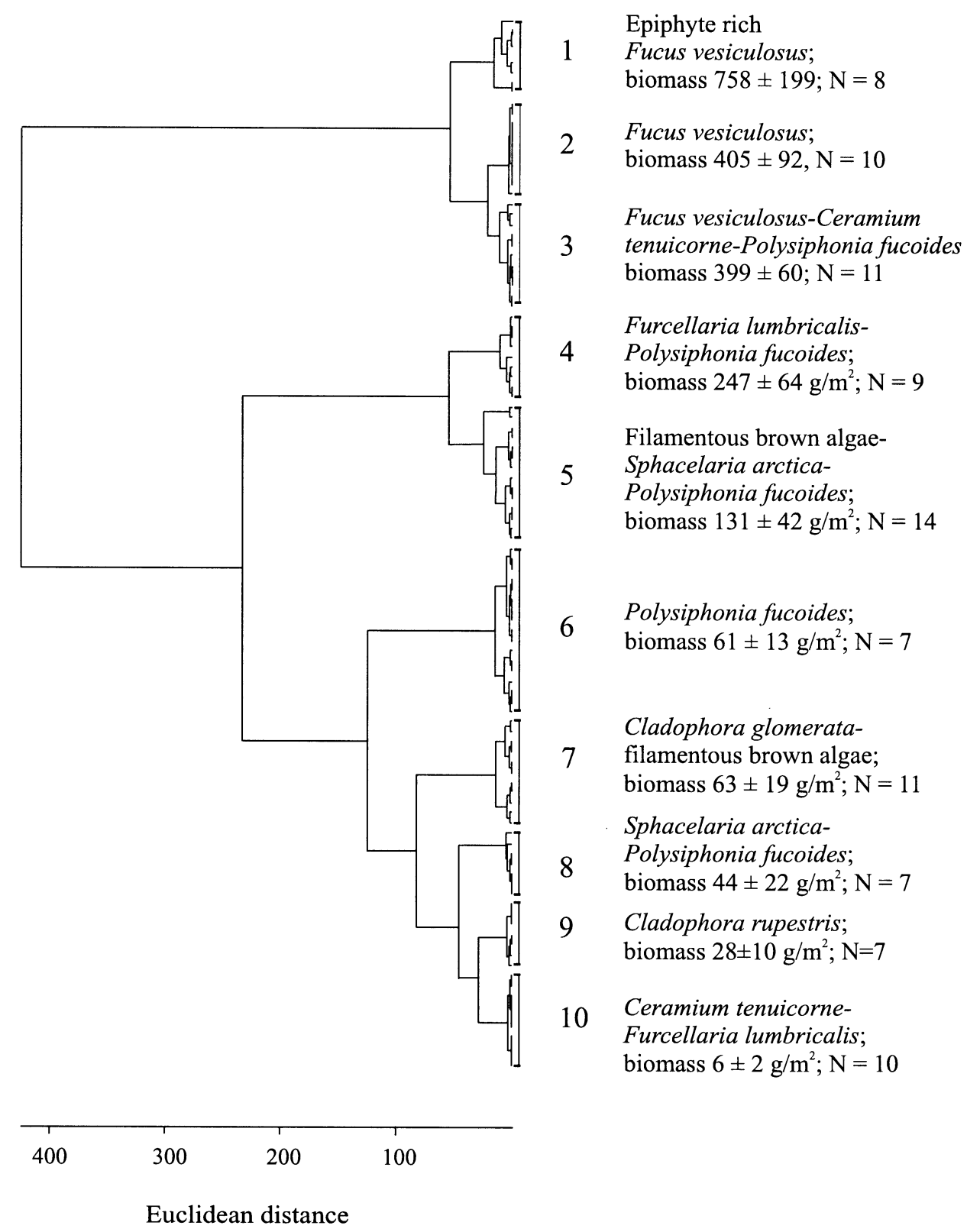

Fig. 2. Classification dendrogram of the phytobenthic microcoenoses. The dominant species, mean biomass value \pm standard error of the mean, and the number of samples in the cluster $(\mathrm{N})$ are shown by the number of the cluster. 


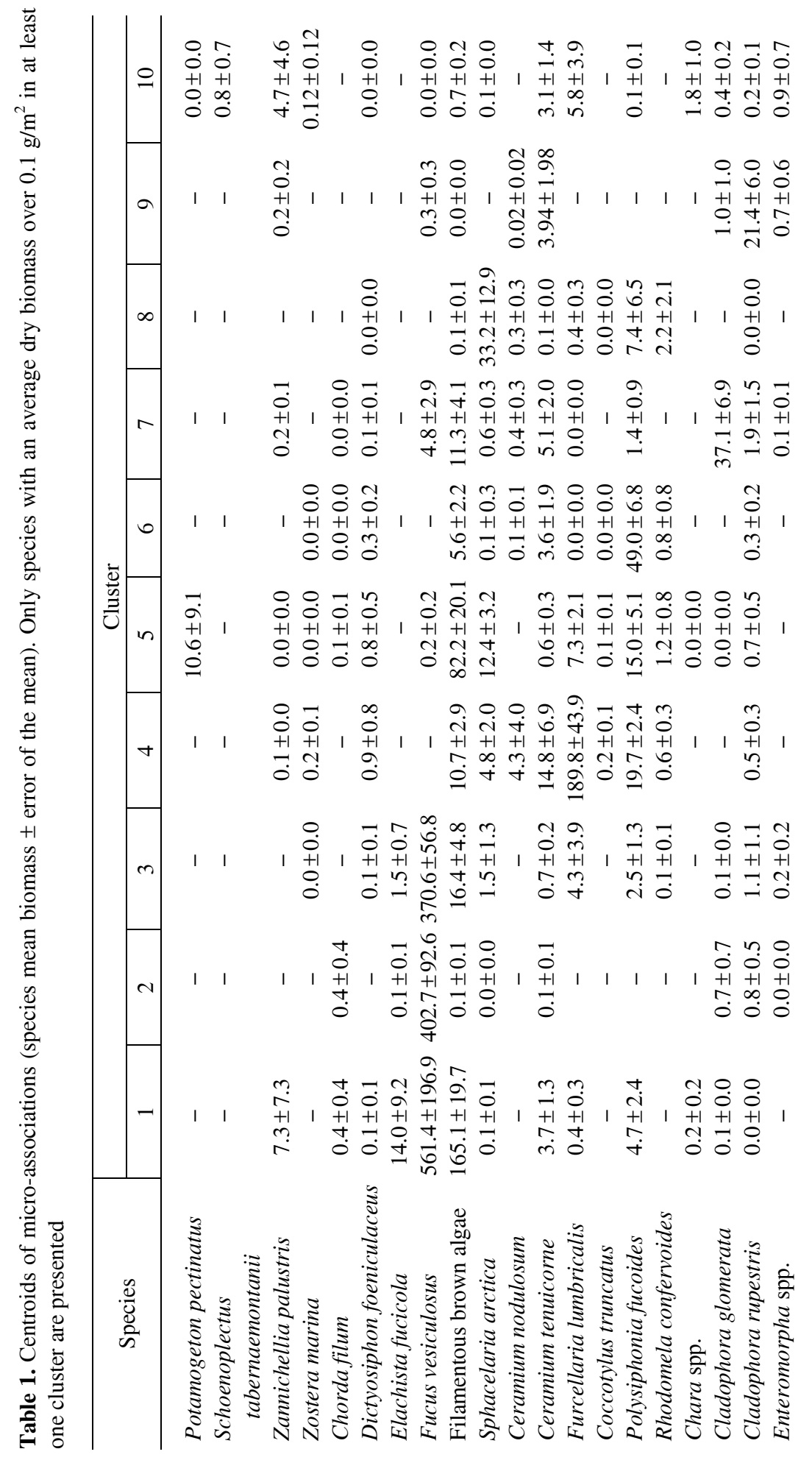


Micro-associations of Furcellaria lumbricalis-Polysiphonia fucoides (cluster 4) and filamentous brown algae-Sphacelaria arctica-Polysiphonia fucoides (cluster 5) form the next rather clearly separated branch on the dendrogram. The remaining five clusters are mutually more related, but still reliably distinct. The 6th cluster can be called the Polysiphonia fucoides micro-association, followed by the Cladophora glomerata-filamentous brown algae micro-association, Sphacelaria arctica-Polysiphonia fucoides micro-association, Cladophora rupestris microassociation, and Ceramium tenuicorne-Furcellaria lumbricalis micro-association (Table 1).

The classification of composite samples resulted in six almost distinct clusters; the cofenetic correlation coefficient of the dendrogram (Fig. 3) is 0.61. Only the

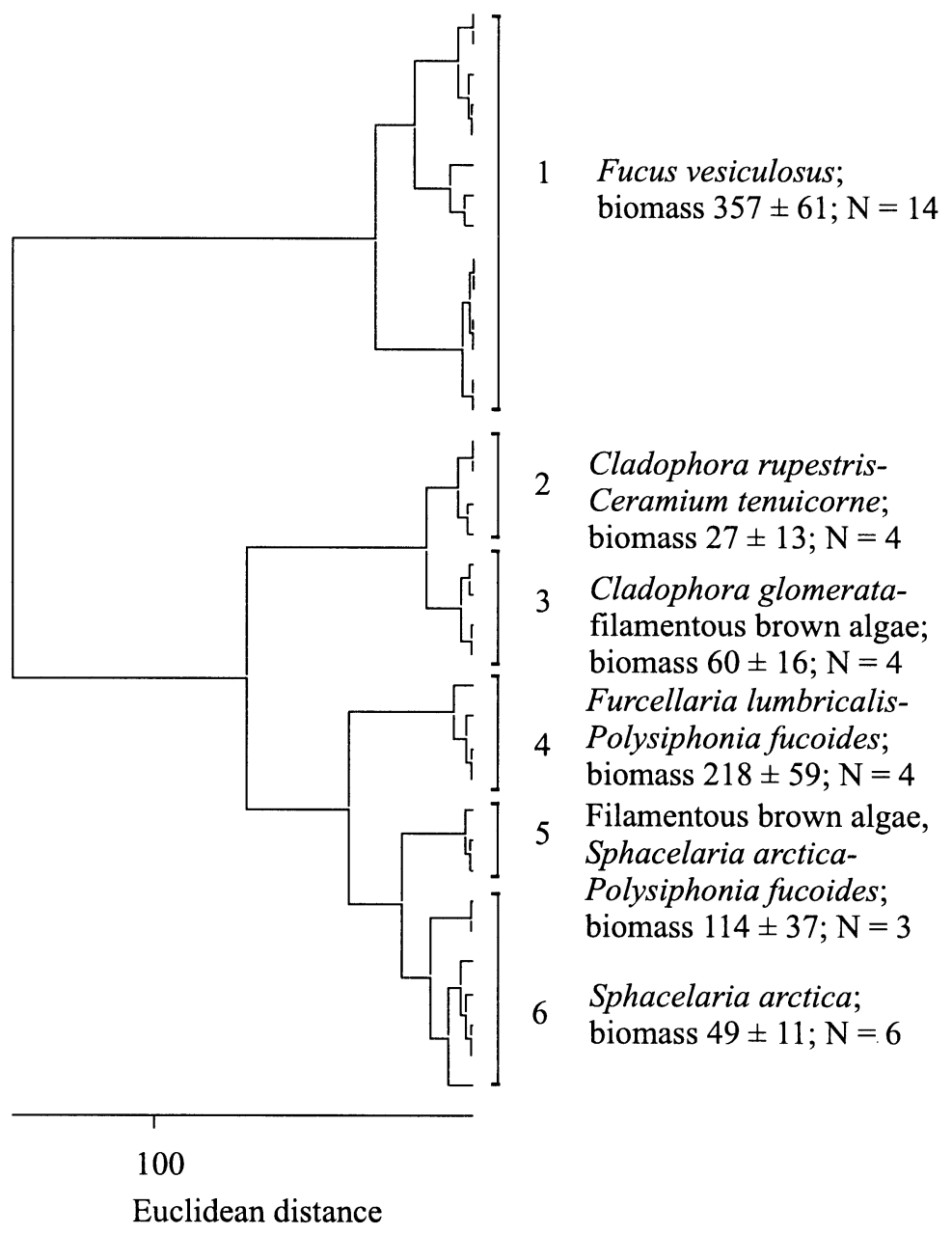

Fig. 3. Classification dendrogram of the composite samples (communities). Notation as in Fig. 2. 
2nd and 6th clusters are not well separated according to statistical testing $\left(\mathrm{CI}_{2,6}=10.9\right)$; the observed indistinctness is caused by the low biomass of the species in both respective clusters in comparison with other clusters rather than by an overlapping species list.

In this classification structure the community type dominated by $F$. vesiculosus is again clearly distinct from the other types (Table 2). The Cladophora rupestrisCeramium tenuicorne and Cladophora glomerata-filamentous brown algae community types constitute the next two quite closely related clusters. The Furcellaria lumbricalis-Polysiphonia fucoides, filamentous brown algaeSphacelaria arctica-Polysiphonia fucoides, and Sphacelaria arctica community types represent the third, and last, larger branch of the dendrogram. It should be stressed here that the three small sample quadrats used for compiling composite samples do not always reliably represent the vegetation on a community scale, therefore the obtained clusters can be interpreted with certain reservations as community types.

Table 2. Centroids of plant communities (species mean \pm error of the mean). Only species with an average dry biomass over $0.1 \mathrm{~g} / \mathrm{m}^{2}$ in at least one cluster are included

\begin{tabular}{l|c|c|c|c|c|c}
\hline \multirow{2}{*}{ Species } & \multicolumn{7}{c}{ Cluster } \\
\cline { 2 - 7 } & 1 & 2 & 3 & 4 & 5 & 6 \\
\hline \multirow{2}{*}{$\begin{array}{l}\text { Potamogeton pectinatus } \\
\text { Schoenoplectus }\end{array}$} & $3.5 \pm 3.0$ & - & - & - & $0.1 \pm 0.2$ & $0.0 \pm 0.0$ \\
$\quad$ tabernaemontanii & - & - & - & - & - & $0.5 \pm 0.5$ \\
Zannichellia palustris & $1.4 \pm 1.4$ & $5.9 \pm 5.9$ & $0.2 \pm 0.1$ & $0.1 \pm 0.0$ & $0.0 \pm 0.1$ & $0.0 \pm 0.1$ \\
Zostera marina & - & - & - & $0.2 \pm 0.1$ & $0.1 \pm 0.1$ & $0.1 \pm 0.1$ \\
Chorda filum & $0.2 \pm 0.1$ & - & $0.0 \pm 0.0$ & $0.1 \pm 0.1$ & - & - \\
Dictyosiphon & $0.1 \pm 0.03$ & $0.0 \pm 0.0$ & $0.1 \pm 0.1$ & $0.8 \pm 0.7$ & $1.2 \pm 2.0$ & $0.1 \pm 0.1$ \\
$\quad$ foeniculaceus & & & & & & \\
Elachista fucicola & $3.1 \pm 2.7$ & - & - & - & - & - \\
Fucus vesiculosus & $283.6 \pm 47.9$ & $5.1 \pm 5.1$ & $4.6 \pm 2.3$ & $20.4 \pm 20.4$ & - & $0.0 \pm 0.0$ \\
Filamentous brown algae & $49.9 \pm 18.9$ & $0.7 \pm 0.4$ & $10.4 \pm 5.2$ & $9.4 \pm 4.2$ & $68.2 \pm 55.1$ & $1.2 \pm 1.1$ \\
Sphacelaria arctica & $0.4 \pm 0.2$ & - & $0.5 \pm 0.5$ & $4.8 \pm 2.5$ & $18.5 \pm 9.4$ & $11.7 \pm 7.0$ \\
Ceramium nodulosum & - & $0.0 \pm 0.0$ & $0.4 \pm 0.4$ & $3.2 \pm 3.0$ & - & $0.2 \pm 0.1$ \\
Ceramium tenuicorne & $1.8 \pm 0.6$ & $3.3 \pm 1.6$ & $4.7 \pm 2.9$ & $11.4 \pm 6.2$ & $0.2 \pm 0.0$ & $2.8 \pm 1.7$ \\
Furcellaria lumbricalis & $2.0 \pm 1.2$ & - & $0.0 \pm 0.0$ & $142.6 \pm 35.9$ & $7.3 \pm 5.3$ & $4.2 \pm 2.6$ \\
Coccotylus truncatus & - & - & - & $0.1 \pm 0.1$ & $0.1 \pm 0.2$ & - \\
Polysiphonia fucoides & $9.9 \pm 4.2$ & - & $1.3 \pm 0.9$ & $24.0 \pm 5.7$ & $16.2 \pm 24.1$ & $4.0 \pm 11.7$ \\
Rhodomela confervoides & - & - & - & $0.5 \pm 0.3$ & $1.8 \pm 2.9$ & $1.7 \pm 1.1$ \\
Chara spp. & $0.0 \pm 0.0$ & - & - & - & $0.0 \pm 0.0$ & $1.3 \pm 1.3$ \\
Cladophora glomerata & $0.2 \pm 0.2$ & $0.1 \pm 0.1$ & $34.6 \pm 9.2$ & - & - & $0.2 \pm 0.2$ \\
Cladophora rupestris & $1.0 \pm 0.5$ & $11.5 \pm 6.1$ & $2.5 \pm 1.7$ & $0.8 \pm 0.5$ & $0.0 \pm 0.0$ & $0.0 \pm 0.0$ \\
Enteromorpha spp. & $0.1 \pm 0.0$ & $0.0 \pm 0.0$ & $0.5 \pm 0.4$ & - & - & $0.6 \pm 0.6$
\end{tabular}




\section{Micro-associations and community types}

Comparison of microcoenoses and communities shows that on both scales the most frequent classification units, dominated by $F$. vesiculosus, are conspicuously heterotoneous. On the microcoenosis scale, three variants of the respective microassociation were established; on the community scale, the corresponding branch of the dendrogram consists also of three sub-branches (Fig. 3). Since the input data for cluster analysis were different in both cases, we cannot find a one-to-one correspondence between the two considered clusters. However, if the position of single microcoenoses belonging to various clusters is traced, the microassociation variants are in general reflected also as community type variants. In addition, the composite samples that form the Fucus vesiculosus community type include several samples from the filamentous brown algae-Sphacelaria arcticaPolysiphonia fucoides, Polysiphonia fucoides, and Ceramium tenuicorneFurcellaria lumbricalis micro-associations (Table 3). Many authors (Wærn, 1952; Kangas et al., 1982; Kautsky, 1988; etc.) have also emphasized the spatial heterogeneity of the $F$. vesiculosus dominated communities.

In the communities of Cladophora rupestris-Ceramium tenuicorne type the microcoenoses of the Cladophora rupestris and Ceramium tenuicorne-Furcellaria lumbricalis micro-associations are almost equally represented (Table 3). The

Table 3. Correspondence between the phytobenthic micro-associations and community types

\begin{tabular}{|c|c|c|c|c|c|c|}
\hline \multirow{2}{*}{ Micro-association } & \multicolumn{6}{|c|}{ Community type* } \\
\hline & 1 & 2 & 3 & 4 & 5 & 6 \\
\hline $\begin{array}{l}\text { 1. Epiphyte rich } \\
\text { Fucus vesiculosus }\end{array}$ & 8 & - & - & - & - & - \\
\hline 2. Fucus vesiculosus & 10 & - & - & - & - & - \\
\hline $\begin{array}{l}\text { 3. Fucus vesiculosus and } \\
\text { other species }\end{array}$ & 10 & 1 & - & - & - & - \\
\hline $\begin{array}{l}\text { 4. Furcellaria lumbricalis- } \\
\text { Polysiphonia fucoides }\end{array}$ & - & - & - & 9 & - & - \\
\hline $\begin{array}{c}\text { 5. Filamentous brown algae- } \\
\text { Sphacelaria arctica- } \\
\text { Polysiphonia fucoides }\end{array}$ & 5 & - & - & - & 9 & - \\
\hline 6. Polysiphonia fucoides & 5 & - & - & 2 & - & 10 \\
\hline $\begin{array}{l}\text { 7. Cladophora glomerata- } \\
\text { filamentous brown algae }\end{array}$ & - & - & 11 & - & - & - \\
\hline $\begin{array}{l}\text { 8. Sphacelaria arctica- } \\
\text { Polysiphonia fucoides }\end{array}$ & - & - & - & - & - & 7 \\
\hline 9. Cladophora rupestris & - & 6 & 1 & - & - & - \\
\hline $\begin{array}{l}\text { 10. Ceramium tenuicorne- } \\
\text { Furcellaria lumbricalis }\end{array}$ & 4 & 5 & - & - & - & 4 \\
\hline
\end{tabular}

* The number of microcoenoses of different type $(0.2 \times 0.2 \mathrm{~m}$ samples $)$ included in the respective community type. For names of community types see Fig. 3. 
Cladophora glomerata-filamentous brown algae community type and the consubstantial micro-association are very similar to each other, the same can be followed by Furcellaria lumbricalis-Polysiphonia fucoides community type and micro-association. Other authors have not referred to the heterotoneity of these communities either. The communities of filamentous brown algae-Sphacelaria arctica-Polysiphonia fucoides include only the samples from the respective microcoenoses. In the communities of Sphacelaria arctica type the microcoenoses of Polysiphonia fucoides, Sphacelaria arctica-Polysiphonia fucoides, and Ceramium tenuicorne-Furcellaria lumbricalis are represented. There is no corresponding community type for the Polysiphonia fucoides micro-association. Therefore, in the course of averaging and new clustering, the samples of these microcoenoses were distributed between the Fucus vesiculosus, Furcellaria lumbricalisPolysiphonia fucoides, and Sphacelaria arctica community types.

\section{Distribution of microcoenoses}

The Fucus vesiculosus micro-associations are the most widely represented in the study area (Fig. 4). The microcoenoses dominated by F. lumbricalis and $P$. fucoides were found only near Vormsi Island. The microcoenoses of filamentous brown algae-Sphacelaria arctica-Polysiphonia fucoides type occur in the coastal waters of Vormsi Island (Tjuka) and Saaremaa Island (Kaugatuma, Küdema). The Polysiphonia fucoides type microcoenoses were found from Küdema, Kõpu, Saxby, and Nõva; microcoenoses of Cladophora glomerata-filamentous brown algae type were found from Kaugatuma, Küdema, and Nõva. Microcoenoses of the Sphacelaria arctica-Polysiphonia fucoides micro-association were represented only at Kõiguste and Eru, while microcoenoses of Cladophora rupestris and Ceramium tenuicorne-Furcellaria lumbricalis type occurred only in sites along the coast of the Gulf of Finland.

The limited geographical distribution of certain types of microcoenoses can be explained by the salinity range of the species. No Furcellaria lumbricalisPolysiphonia fucoides microcoenoses were found in the Gulf of Finland, probably because of salinity limitation. Furcellaria lumbricalis communities have previously been found only in waters with a salinity higher than 5.8\%o (Kukk, 1978; Trei, 1991). The distribution of samples with $P$. fucoides is concentrated in the western part of the study area. The salinity boundary of this species lies in the middle of the Gulf of Finland (Kukk, 1979; Trei, 1991), and it occurs in abundance on the shores of western Estonia. Only the Sphacelaria arcticaPolysiphonia fucoides type microcoenoses, where the biomass of both species is very low, occur at Eru in the Gulf of Finland.

The distribution pattern of the Cladophora glomerata-filamentous brown algae microcoenoses and the Ceramium tenuicorne-Furcellaria lumbricalis microcoenoses (Fig. 4) can be caused by the seasonal variability of dominating annual species. The sampling in the Gulf of Finland was carried out in early 

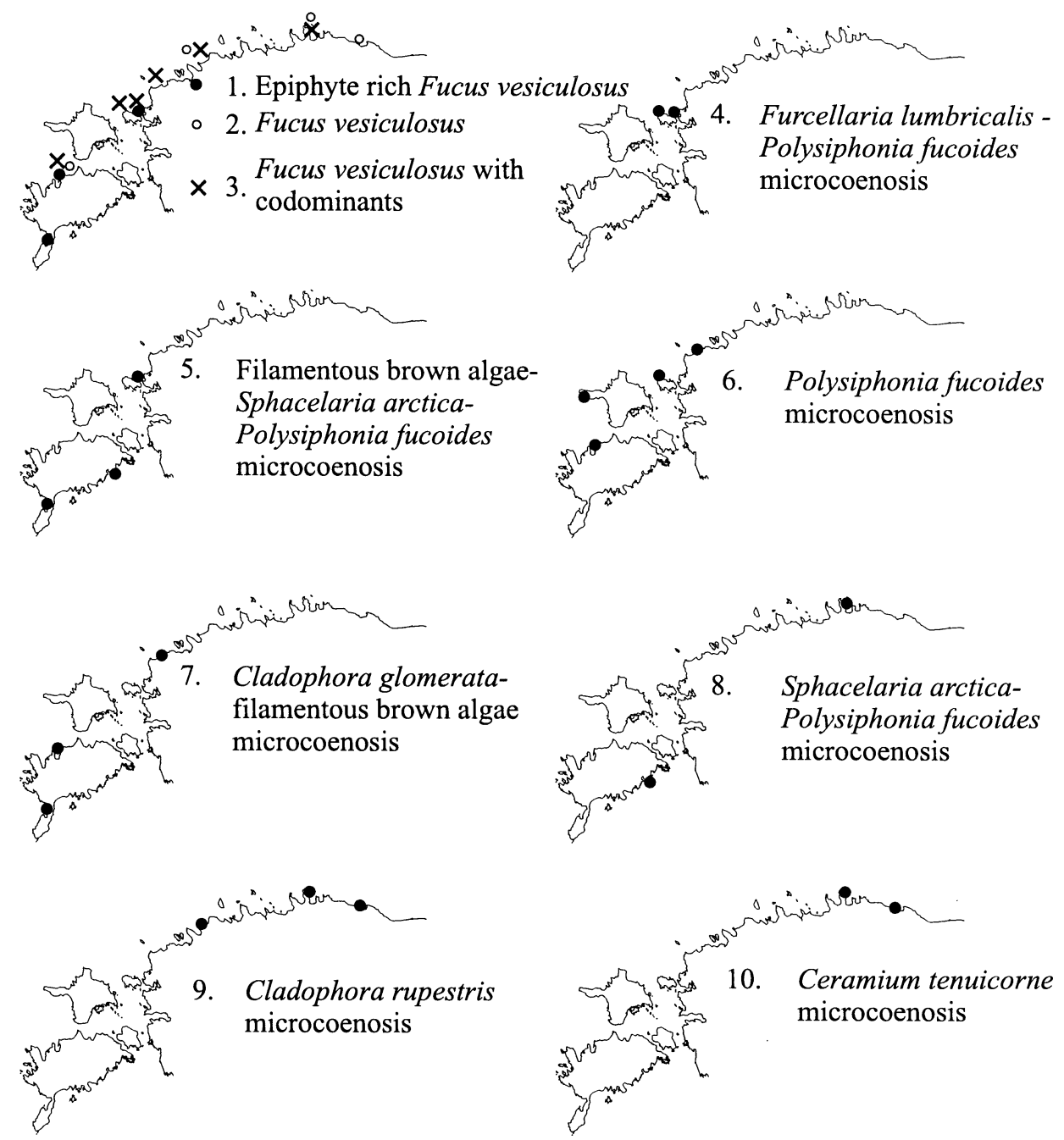

Fig. 4. Distribution of the different types of microcoenoses in the study sites.

October and, in western Estonia, at the end of August. The biomass of the green algae C. glomerata is usually declining towards autumn (Kukk, 1979), so the C. glomerata dominated areas could no longer be found in October and the low biomass of the Ceramium tenuicorne-Furcellaria lumbricalis microcoenoses was identified instead. C. tenuicorne is one of the most frequent species in the study area, found in small amounts in every studied site, but only in the Eru and Kunda transects did it dominate and form its own microcoenoses. 


\section{Dependence of microcoenoses on environmental conditions}

According to ANOVA, the largest difference between the microcoenoses of different micro-associations appears in their depth range $(F=13.4, p<0.001)$ (Fig. 5). Microcoenoses of Cladophora glomerata-filamentous brown algae, Cladophora rupestris, and Fucus vesiculosus and Ceramium tenuicorne-Furcellaria lumbricalis micro-associations are growing in shallow $(0.2-3 \mathrm{~m})$ water. The Sphacelaria arctica-Polysiphonia fucoides type microcoenoses can be found at a depth of 6-8 m. The filamentous brown algae-Sphacelaria arctica-Polysiphonia fucoides, Furcellaria lumbricalis-Polysiphonia fucoides, and Polysiphonia fucoides type microcoenoses occur over a large depth range $(0.5-11 \mathrm{~m})$.

The difference in substrate hardness between the (micro)habitats of microcoenoses belonging to different types is not significant. Although the study sites were chosen in exposed areas, microcoenoses of some micro-associations differ

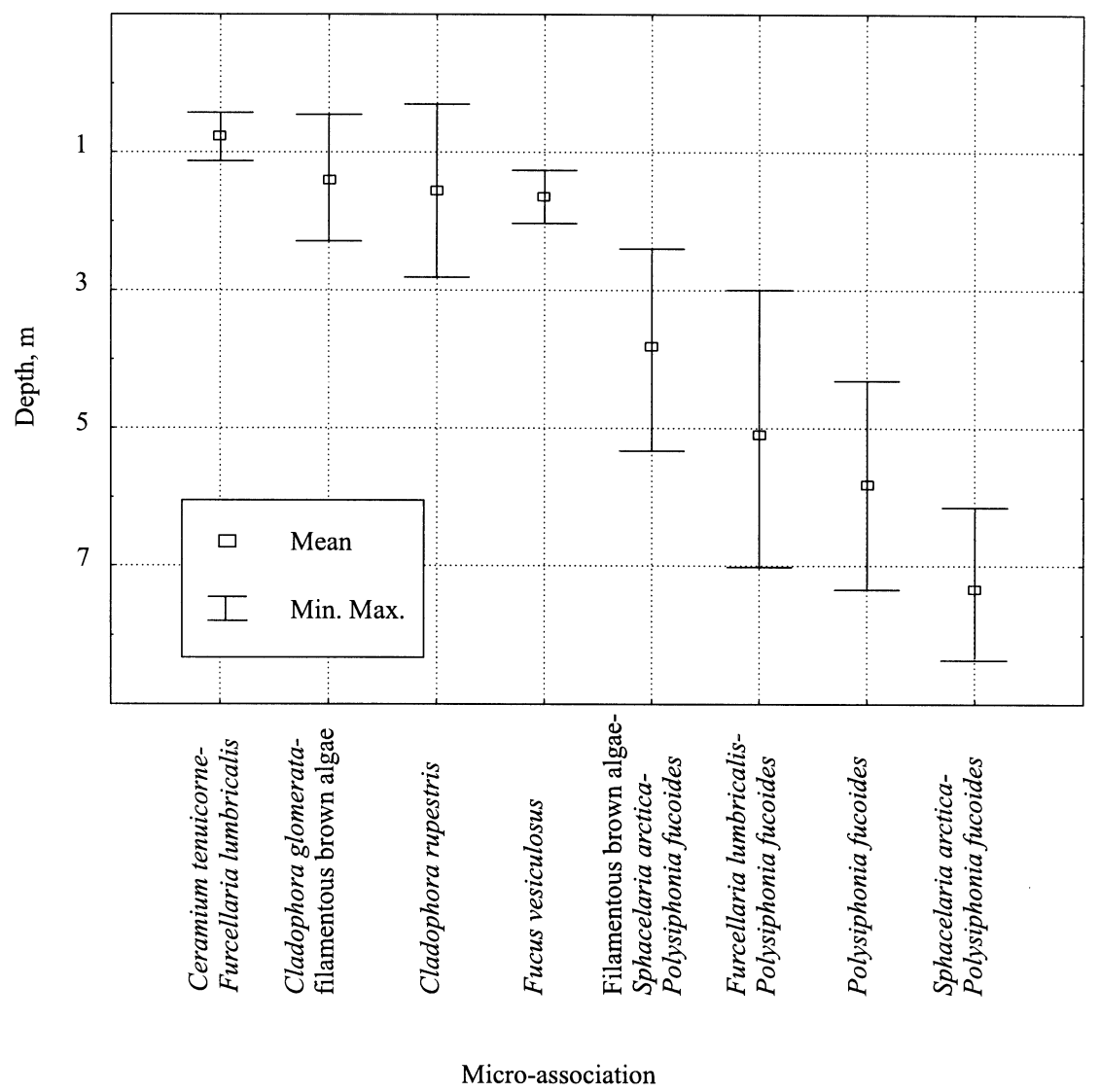

Fig. 5. Growth depth of the different types of microcoenoses. Minimum-maximum and mean depth are shown in every micro-association. 
in their exposure range $(F=7.7, p<0.001)$ : the microcoenoses of Furcellaria lumbricalis-Polysiphonia fucoides and the micro-associations of Polysiphonia fucoides grow in the most exposed sites, while the filamentous brown algaeSphacelaria arctica-Polysiphonia fucoides type microcoenoses occupy more sheltered sites.

Ordination analysis verified the results of the ANOVA and gave a generalized overview of species-environment relations (Fig. 6). The Monte Carlo permutation test confirmed the significance of the first two canonical axes $(p=0.005)$. According to the forward selection procedure, only depth and exposure are statistically significant ( $p=0.005$ ) environmental factors in describing the species variation (Table 4). Habitat depth is closely related to the first ordination axis. According to that, the red algae Rhodomela confervoides, Coccotylus truncatus, Polysiphonia fucoides, Ceramium nodulosum, and Furcellaria lumbricalis and the brown algae Sphacelaria arctica and Stictyosiphon tortilis, growing mainly in deep water, are located on the right side of the ordination plot. Chara spp., the brown algae Chorda filum and F. vesiculosus, the green algae Cladophora

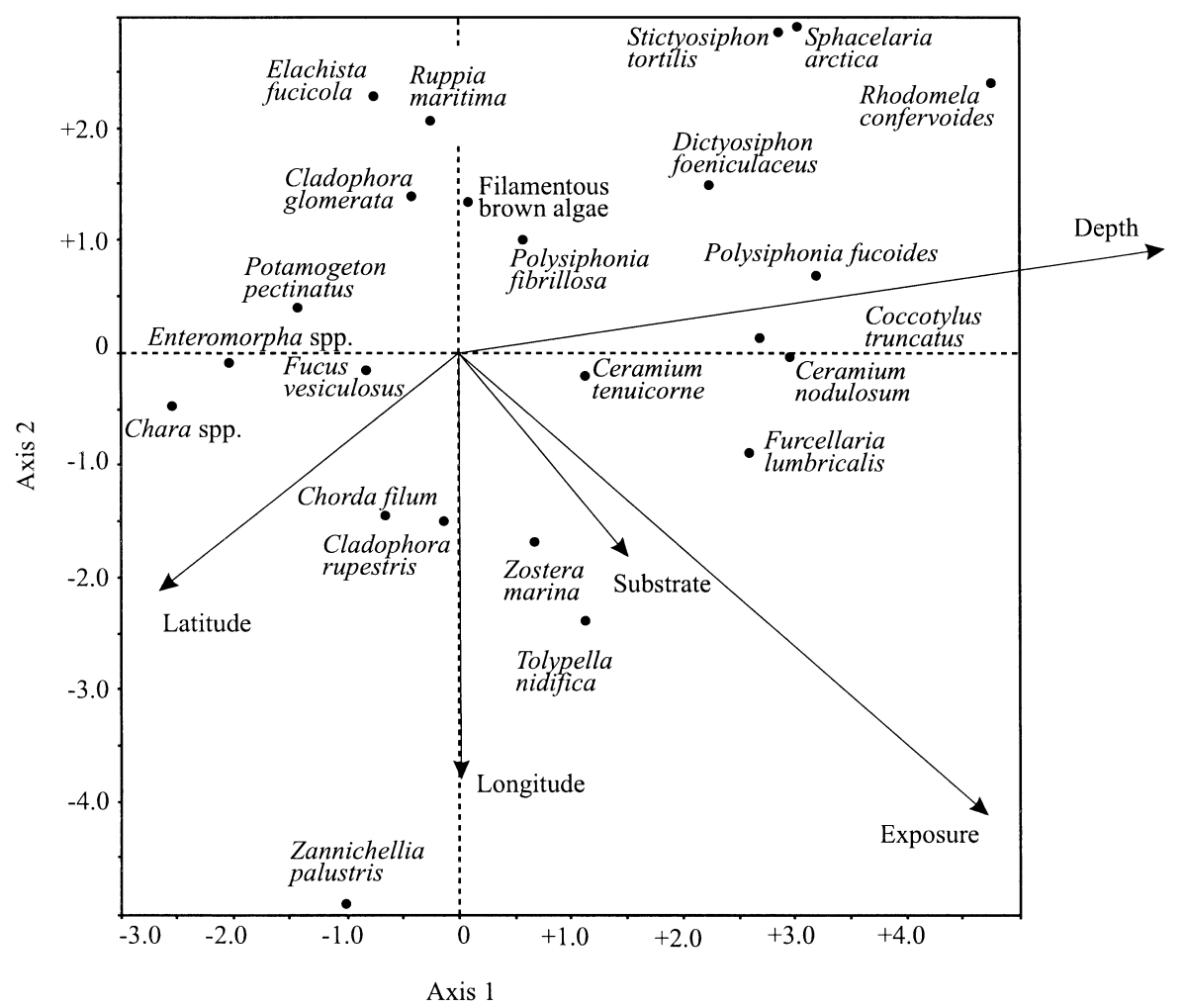

Fig. 6. Ordination biplot of the phytobenthic species and the environmental variables according to canonical correspondence analysis. 
Table 4. Conditional effects of the environmental factors according to canonical correspondence analysis. $F-F$-criterion, $p-$ significance level

\begin{tabular}{lcc}
\hline \multicolumn{1}{c|}{ Factor } & $F$ & $p$ \\
\hline Depth & 8.34 & 0.005 \\
Exposure & 3.25 & 0.005 \\
Latitude & 1.71 & 0.080 \\
Longitude & 1.30 & 0.215 \\
Substrate & 1.13 & 0.300
\end{tabular}

glomerata and Enteromorpha spp., and the higher plants Potamogeton pectinatus and Zannichellia palustris, placed at the negative end of the ordination axis, occur in shallow water.

Several environmental factors are related to the second ordination axis. Location of some species is obviously connected with geographic parameters longitude and latitude, e.g. Z. palustris, mainly found from sites in the Gulf of Finland, is situated at the negative end of the axis. Exposure and substrate hardness are related more or less equally to both ordination axes. Zostera marina and Tolypella nidifica, which are placed towards the positive end of axis one and negative end of axis two, grow in exposed sites on a sandy substrate. Potamogeton pectinatus, Ruppia maritima, and Cladophora glomerata prefer moderately exposed sites.

Many authors (Wærn, 1952; Hällfors et al., 1987; Nielsen \& Dahl, 1992) stress the influence of substrate on the heterogeneity of the benthic communities. In the present study the substrate hardness was estimated as average for the whole vegetation belt and not for each $0.2 \times 0.2 \mathrm{~m}$ square. For that reason the relationship between substrate hardness and heterogeneity of communities does not come to the fore. Moreover, in most of the study area the substrate consisted of a mixture of sand and stones, and the substrate hardness did not differ greatly between the sites.

In their discussion about environmental influences on the species distribution in the Gulf of Riga, Kautsky et al. (1999) emphasized, besides the influence of substrate, the effect of depth. Our findings agree with the results of Kautsky \& van der Maarel (1990) from the eastern coast of Sweden, showing that the main environmental factor determining the distribution of benthic vegetation is depth. As discussed above, the transects of the current study were located in areas with similar substrate type (mostly mixed). In different parts of the Gulf of Riga the substrate and water quality conditions are very variable and that is why the substrate appeared to be the most important environmental factor for the phytobenthos (Kautsky et al., 1999). Our study area did not cover the arms of the Gulf of Riga and Gulf of Finland; thus the range of environmental factors was relatively narrow. Still a difference in species composition between open sea areas and gulfs could be detected. 


\section{Comparison with previous classifications}

In our study the samples were collected only from relatively exposed shores with hard and mixed substrates. Therefore, comparison with previous classifications of phytobenthic communities in Estonia (Trei, 1973, 1991; Kukk, 1978, 1979; Martin et al., 2000) and on the eastern coast of Sweden (Kautsky \& van der Maarel, 1990) is relevant only within the limits of similar habitats.

Of the six community types established in the current study, only two (Fucus vesiculosus and Cladophora glomerata types) are described by all the authors cited in Table 5. It deserves to be noted here that according to Trei $(1973,1991)$ the community of Fucus vesiculosus is the most frequent one in Estonian waters, occurring at depths from 1 to 7 (9) $\mathrm{m}$. In our study the Fucus vesiculosus

Table 5. Comparison of current results with other phytobenthic community classifications

\begin{tabular}{|c|c|c|c|c|c|}
\hline Community type & $\begin{array}{l}\text { Trei, } \\
1973, \\
1991 \\
\end{array}$ & $\begin{array}{l}\text { Kukk, } \\
1978, \\
1979 \\
\end{array}$ & $\begin{array}{c}\text { Kautsky \& van } \\
\text { der Maarel, } 1990\end{array}$ & $\begin{array}{l}\text { Martin et } \\
\text { al., } 2000\end{array}$ & Current data \\
\hline Fucus vesiculosus & + & + & + & + & + \\
\hline $\begin{array}{l}\text { Cladophora rupestris- } \\
\text { Ceramium tenuicorne }\end{array}$ & - & - & - & - & + \\
\hline Cladophora glomerata & + & + & + & + & + \\
\hline $\begin{array}{l}\text { Furcellaria lumbricalis- } \\
\qquad \text { Polysiphonia fucoides }\end{array}$ & - & - & - & + & + \\
\hline $\begin{array}{l}\text { Filamentous brown algae - } \\
\text { Sphacelaria arctica- } \\
\text { Polysiphonia fucoides }\end{array}$ & + & + & - & - & + \\
\hline $\begin{array}{l}\text { Polysiphonia fucoides- } \\
\text { Sphacelaria arctica }\end{array}$ & + & - & - & - & + \\
\hline Ceramium tenuicorne & - & - & + & + & - \\
\hline $\begin{array}{l}\text { Cladophora glomerata- } \\
\text { Enteromorpha spp. }\end{array}$ & - & - & - & + & - \\
\hline Cladophora rupestris & - & - & - & + & - \\
\hline Enteromorpha spp. & + & + & + & - & - \\
\hline Filamentous brown algae & + & + & - & + & - \\
\hline $\begin{array}{l}\text { Fucus vesiculosus- } \\
\qquad \text { Furcellaria lumbricalis }\end{array}$ & + & + & - & - & - \\
\hline Furcellaria lumbricalis & + & + & - & + & - \\
\hline $\begin{array}{l}\text { Furcellaria lumbricalis- } \\
\text { Ceramium nodulosum }\end{array}$ & + & - & + & - & - \\
\hline $\begin{array}{l}\text { Furcellaria lumbricalis - } \\
\text { Polysiphonia fucoides- } \\
\text { Ceramium tenuicorne }\end{array}$ & + & - & + & - & - \\
\hline $\begin{array}{l}\text { Pseudolithoderma } \\
\text { subextensum }\end{array}$ & + & + & - & - & - \\
\hline Rhodomela confervoides & - & + & - & - & - \\
\hline
\end{tabular}


communities were also the most frequent, but their depth range had narrowed considerably, to only 1-3 m. This result can be partly connected with the comparatively limited geographical representativeness and ecological range of the study sites. Still, the community of Fucus vesiculosus-Furcellaria lumbricalis, found at depths of 6-10 m in earlier studies (Trei, 1973, 1991; Kukk, 1978, 1979), was recorded neither by Martin et al. (2000) nor by us. It seems that while the depth range of $F$. vesiculosus has decreased, the deep-growing community of Fucus vesiculosus-Furcellaria lumbricalis has disappeared.

The community of Cladophora rupestris was noted by Martin et al. (2000), and, as the respective microcoenosis, also in our study, but not earlier by Trei (1973, 1991) and Kukk $(1978,1979)$. The last two authors described a Fucus vesiculosus community with an under-growing layer of Cladophora rupestris. $C$. rupestris is probably still growing in the former $F$. vesiculosus area. Nevertheless, this is just a speculation, since there are no observations from exactly the same spots. Large-scale decline of $F$. vesiculosus, documented in different parts of the Baltic Proper (Kangas et al., 1982; Mäkinen et al., 1984; Vogt \& Schramm, 1991; Rönnberg et al., 1995; Schramm \& Nienhuis, 1996), has not yet been observed in the eastern Baltic Proper. It was suggested that the reason for the decline of this species was an increase in nutrient concentration, inducing luxurious growth of annual epiphytic algae, which in turn reduces the vitality of F. vesiculosus due to competition for light and nutrients (Kangas et al., 1982; Vogt \& Schramm, 1991; Schramm \& Nienhuis, 1996). In deep water the competition for light is fiercer and therefore $F$. vesiculosus is out-competed first of all in the deeper parts of its distribution area. In the recent study area $F$. vesiculosus has not entirely disappeared, but there are signs of its decline even though our study sites were chosen in the outer parts of bays, representing the conditions without direct land-born nutrient sources. Kukk \& Martin (1992) recorded a considerable decrease in $F$. vesiculosus constancy in Pärnu Bay; Kotta et al. (2000) observed the disappearance of $F$. vesiculosus from Kõiguste Bay during 1995-98. Thus the F. vesiculosus decline may be more extensive in sheltered sites close to river inputs.

The community type of Cladophora rupestris-Ceramium tenuicorne has not been described by previous authors, but communities of Cladophora rupestris (Martin et al., 2000) and Ceramium tenuicorne (Kautsky \& van der Maarel, 1990; Martin et al., 2000) have been described separately. In our study the latter two were separated as micro-associations. The community of Furcellaria lumbricalisPolysiphonia fucoides has only been described in the present paper and in Martin et al. (2000), not in earlier studies, therefore it is difficult to decide whether we have a true temporal change here, or whether the discrepancies appeared due to the different research methods. The community of Polysiphonia fucoidesSphacelaria arctica has only been considered in the present paper and in Trei (1973, 1991).

More than half of the communities listed in Table 5 were not observed in the present paper. The reasons for this could be the narrow amplitude of environmental 
conditions covered by the present study and the small number of sampling sites (rare community of Rhodomela confervoides). Some of the differences are caused by different sampling methods - for example, the encrusted brown alga Pseudolithoderma subextensum did not occur in quantitative samples because it is so tightly attached to stones. The diversity in community names can also be caused by different emphasis put on dominant and character species.

Even though the sampling pattern was not designed for analysing the heterogeneity of communities, it is the first attempt to analyse benthic vegetation on the microcoenoses level in Estonia. Broadening of the study area and the study period would give a better picture of Estonian benthic communities and their mosaic-like pattern, and would test some of the conjectures about distribution presented in this paper.

\section{ACKNOWLEDGEMENTS}

The sampling was done in the frame of the national programme "Läänemere vetikavarude kui taastuva loodusvara säästlik ja majanduslikult optimaalne kasutamine". We thank the staff of the Estonian Marine Institute, especially Jonne Kotta and Helen Orav, for their help in sample collection and sample analysis, and Ilmar Part for revising the English.

\section{REFERENCES}

Baardseth, E. 1970. A square-scanning, two stage sampling method of estimating seaweed quantities. Norw. Inst. Seaweed Res. Rep., 33.

Barkman, J. J. 1964. Das synsüstematische Problem der microgesellschaften innerhalb der Biozönosen. In Berichte über die Internationalen Symposia der internationalen Vereinigung für Vegetationskunde, Vol. 3 (Tüxen, R., ed.), pp. 21-53. Dr. W. Junk Publishers, The Hague.

Dahl, E. 1957. Rondane mountain vegetation in South Norway and its relation to the environment. Skr. utgitt av Det norske vid.-akad. i Oslo. I. Mat.- naturv. klasse, 1956.

Duda, R. \& Hart, P. 1976. Pattern Classification and Scene Analysis. Mir, Moskva (in Russian).

Fischer, J. L. 1778. Versuch einer Naturgeschichte von Livland. Leipzig.

Gauch, H. G. Jr. 1982. Multivariate Analysis in Community Ecology. Cambridge University Press.

Gobi, C. 1874. Die Brauntange (Phaeosporeae und Fucaceae) des Finnischen Meerbusens. Mem. de l'acad. Imp. Sci. de Petersbourg, VII Ser., 21(9).

Gobi, C. 1877. Die Rothtange des Finnischen Meerbusens. Mem. de l'acad. Imp. Sci. de Petersbourg, VII Ser., 24(7).

Hällfors, G., Viitasalo, I. \& Niemi, A. 1987. Macrophyte vegetation and trophic status of the Gulf of Finland. A review of Finnish investigations. Meri, 13, 111-158.

Häyrén, E. 1929-30. Einige Algenfunde an den Meeresküsten Estlands. Mem. Soc. Fauna Flora Fenn., 6, 174-179.

Kangas, P., Autio, H., Hällfors, G., Luther, H., Niemi, Å. \& Salemaa, H. 1982. A general model of the decline of Fucus vesiculosus at Tvärminne, south coast of Finland in 1977-81. Acta Bot. Fenn., 118, 1-27. 
Kautsky, H. 1988. Factors structuring phytobenthic communities in the Baltic Sea. Doctoral dissertation, Dept. Zoology, Stockholm University.

Kautsky, H. \& van der Maarel, E. 1990. Multivariate approaches to the variation in phytobenthic communities and environmental vectors in the Baltic Sea. Mar. Ecol. Prog. Ser., 60, 169184.

Kautsky, H., Martin, G., Mäkinen, A., Borgiel, M., Vahteri, P. \& Rissanen, J. 1999. Structure of phytobenthic and associated animal communities in the Gulf of Riga. Hydrobiologia, 393, $191-200$.

Kiirikki, M. 1996. Dynamics of macroalgal vegetation in the northern Baltic Sea - evaluating the effects of weather and eutrophication. Walter and Andree de Notbeck Foundation Scientific Reports, 12. Helsinki.

Korchagin, A. A. 1976. Structure of plant communities. In Field Geobotany, Vol. 5 (Lavrenko, E. M. \& Korchagin, A. A., eds.), pp. 1-320. Nauka, Leningrad (in Russian).

Kotta, J., Orav, H., Martin, G. \& Mäkinen, A. 2000. Major changes in macroalgae assemblage composition affect the food and habitat preference in Idotea baltica. Int. Rev. Hydrobiol., 85, 693-701.

Kukk, H. A. 1978. Bottom vegetation in the southern coastal waters of the Gulf of Finland. Bot. zh., 63, 844-852 (in Russian).

Kukk, H. A. 1979. Benthic vegetation of the Gulf of Finland along the coastal waters of the Soviet Union. Cand. Sci. dissertation, Dept. of Botany and Ecology, Tartu (in Russian).

Kukk, H. \& Martin, G. 1992. Long-term dynamics of the phytobenthos in Pärnu Bay, the Baltic Sea. Proc. Estonian Acad. Sci. Ecol., 2, 110-118.

Leht, M. (ed.) 1999. Eesti taimede määraja. Eesti Loodusfoto, Tartu.

Mäkinen, A., Haahtela, I., Ilvesalo, H., Lehto, J. \& Rönnberg, O. 1984. Changes in the littoral rocky shore vegetation in Seili area, SW Archipelago of Finland. Ophelia Suppl., 3, 157-166.

Martin, G. 1999. Distribution of phytobenthos in the Gulf of Riga (years 1984-1991). Hydrobiologia, 393, 181-190.

Martin, G., Torn, K., Oulasvirta, P. \& Leinikki, J. 2000. Phytobenthic communities of WestEstonian Archipelago area based on three investigated sample areas. In Martin, G. Phytobenthic Communities of the Gulf of Riga and the Inner Sea of the West-Estonian Archipelago. Dissertationes Biologicae Universitatis Tartuensis, 64, pp. 84-104. Tartu University Press.

Nielsen, R. \& Dahl, K. 1992. Marine algae south of the island Verjø, the Sams $\varnothing$ area, Denmark. In Phycological Studies of Nordic Coastal Waters. A Festschrift Dedicated to Prof. Mats Warn on His 80th Birthday (Wallentinus, I., Snoeijs, P., eds.), Acta Phytogeogr. Suec., 78, 111-116.

Nielsen, R., Kristiansen, A., Mathiesen, L. \& Mathiesen, H. (eds.) 1995. Distributional index of the benthic macroalgae of the Baltic Sea area. Acta Bot. Fenn., 155.

Nordhagen, R. 1943. Sikilsdalen og Norges fjellbeiter. En plantesosialogisk monografi. Bergens museums skr., 22.

Paal, J. 1987. Taxonomic continuum, some problems and methods for its quantitive analysis. In The Plant Cover of the Estonian SSR. Flora, Vegetation and Ecology (Laasimer, L. \& Kull, T., eds.), pp. 108-122. Valgus, Tallinn.

Podani, J. 1993. SYN-TAX-pc. Computer Programs for Multivariate Data Analysis in Ecology and Systematics. Version 5.0. User's Guide. Scientia Publishing, Budapest.

Podani, J. 1994. Multivariate Data Analysis in Ecology and Systematics. A Methodological Guide to the SYN-TAX 5.0 Package. SPB Academic Publishing bv, The Hague.

Rönnberg, O., Lehto, J. \& Haahtela, I. 1995. Recent changes in occurrence of Fucus vesiculosus in the Archipelago Sea, SW Finland. Ann. Bot. Fenn., 22, 231-244.

Schramm, W. \& Nienhuis, P. H. (eds.) 1996. Marine Benthic Vegetation. Recent Changes and Effects of Eutrophication. Ecological Studies, 123. Springer, Berlin.

Šmilauer, P. 1992. CanoDraw 3.00 LITE User's Guide. Scientia Publishing, Budapest. 
Sokal, R. R. \& Rolf, F. J. 1973. The comparison of dendrograms by objective methods. Taxon, 11, 33-40.

StatSoft, Inc. 1998. STATISTICA for Windows [Computer program manual]. Tulsa OK, USA.

Svedelius, N. 1902. Havsalger fran Dagö. Bot. not., 225-227.

Ter Braak, C. J. F. \& Šmilauer, P. 1998. CANOCO Reference Manual and User's Guide to Canoco for Windows: Software for Canonical Community Ordination (version 4). Microcomputer Power, New York.

Trei, T. 1973. Lääne-Eesti rannikuvee fütobentos. Cand. Sci. dissertation, Dept. of Botany and Ecology, Tartu.

Trei, T. 1991. Taimed Läänemere põhjal. Valgus, Tallinn.

Vogt, H. \& Schramm, W. 1991. Conspicious decline of Fucus in Kiel Bay (Western Baltic): What are the causes? Mar. Ecol. Prog. Ser., 69, 189-194.

Wærn, M. 1952. Rocky-shore algae in the Öregrund Archipelago. Acta Phytogeogr. Suec., 30.

\section{Fütobentiliste mikrotsönooside levik Eesti avatud rannikuvetes}

\section{Triin Reitalu, Jaanus Paal ja Georg Martin}

1998. aasta välihooaja jooksul kogutud biomassiandmete kvantitatiivse analüüsi põhjal on käsitletud Eesti avatud rannikute fütobentilisi mikrotsönoose ja nende levikut mõjutavaid keskkonnafaktoreid. 104 biomassiproovi alusel eristati kaheksa klastrit (mikroassotsiatsiooni). Taimkattevööndite ulatuses keskmistatud andmete põhjal eristus klasteranalüüsil kuus distinktset koosluse tüüpi. Koosluste mosaiiksuse hindamiseks võrreldi kummalgi tasandil saadud klassifikatsioone. Kõige mosaiiksemaks osutus põisadru (Fucus vesiculosus) kooslus, teised kooslused olid märgatavalt homogeensema struktuuriga. Mikrotsönooside lokaalset levikut määravaks peamiseks keskkonnafaktoriks osutus merepõhja sügavus. Enamik mikroassotsiatsioone on piiratud areaaliga, vaid põisadru mikroassotsiatsioon on levinud kogu uurimisalal. 